УДК 378.011.3-051:373.2

DOI:

Оксана Гевко, кандидат педагогічних наук,

дочент кафедри загальної педагогіки та дошкільної освіти Дрогобииького державного педагогічного університету імені Івана Франка

Марія Биців, студентка факультету психологіï, педагогіки та сочіальної роботи Дрогобииького державного педагогічного університету імені Івана Франка

\title{
ОСОБЛИВОСТІ ФОРМУВАННЯ ПРОФЕСІЙНО-ТВОРЧИХ МОЖЛИВОСТЕЙ МАЙБУТНЬОГО ВИХОВАТЕЛЯ
}

У статті розкрито методичні особливості формування професійно-творчих можливостей майбутнього вихователя; виділено мотивачію і основу креативності майбутнього вихователя до здатності професійного зростання, обтрунтовано методологічні принципи і організаційно-педагогічні засади сформованості професійно-творчих можливостей сучасного вихователя. 3'ясовано, що поетапне навчання і використання нетрадиційних методів і форм організачії навчального прочесу, створення організачійнопедагогічних умов для реалізаиії отриманих знань студентами сприятимуть ефективному розвитку професійно-творчих можливостей вихователя майбутнього у педагогічному закладі вищої освіти. Виокремлено, що поетапне навчання і використання нетрадиційних методів і форм організачії навчального процесу, створення організачійно-педагогічних умов для реалізачї отриманих знань студентами сприятимуть ефективному розвитку професійно-творчих можливостей майбутнього вихователя у педагогічному закладі вищої освіти.

Ключові слова: вихователь; викладач; заклад дошкільної освіти; професійно-творчий потенціал; формування.

Jim. 11.

Oksana Hevko, Ph.D.(Pedagogy), Associate Professor of the General Pedagogy and Preschool Education Department

Drohobych Ivan Franko State Pedagogical University Mariya Bytsiv, Student of the Faculty of Psychology, Pedagogy and Social Work Drohobych Ivan Franko State Pedagogical University

\section{FEATURES OF FORMATION OF PROFESSIONALAND CREATIVE OPPORTUNITIES OF THE FUTURE TUTOR}

In the article the methodological peculiarities of formation of professional and creative opportunities of the future educator are substantiated; the state of the researched problems of scientists and educators-methodologists is analyzed; the motivation and the basis of creativity of the future tutor to the ability of professional growth are highlighted, the methodological principles and organizational and pedagogical foundations of the formation of professional and creative capabilities of the modern tutor are clarified. The formation of professional and creative opportunities of the future educator is a purposeful, long-term process of professional formation of the creative personality of the educator. It is established that this process is based on the following methodological principles, which include: recognizing the individuality of a student, taking into account the pedagogical impetus and motivational sphere of the future tutor, their development, creating an equal position of communication partners; creating a creative environment through dialogic interaction. It has been found out that gradual learning and use of non-traditional methods and forms of organization of the educational process, creation of organizational and pedagogical conditions for the realization of the acquired knowledge by students will contribute to the effective development of professional and creative opportunities of the future teacher in the pedagogical institution of higher education. It is emphasized that gradual learning and use of nontraditional methods and forms of organization of the educational process, creation of organizational and pedagogical conditions for realization of the acquired knowledge by students will contribute to effective development of professional and creative opportunities of the future teacher in the pedagogical institution of higher education. formation.

Keywords: a tutor; a teacher; an institution of preschool education; professional and creative potential; a

П

остановка проблеми. Сучасний розвиток суспільства ставить вимоги до якості змісту і технологій педагогіки вищої школи України, альтернатив до вибору нових способівдля перепідготовки та

О. Гевко, М. Биців, 2019 якісної підготовки майбутніх спеціалістів. Серед них особливу ношу займає когорта майбутніх вихователів закладів дошкільної освіти, ефективність професійної діяльності яких сприяють всебічному вихованню дітей 
дошкільного віку. Динамічність суспільного буття і системи дошкільної освіти, ставлять вимоги до вихователів, виконання яких залежить від чинників: творчі задатки, інноваційні форми взаємодії та комунікації, нові ідеї.

Аналіз останніх публікацій. Проблема вивчення професійно-творчого потенціалу досліджується багатьма науковцями та вихователями-методистами. Над вивченням досліджуваної проблеми працюють такі вчені, як А. Богуш, С.Гаврилюк, Н. Гавриш, Н.Гузій,Ю.Калічак, Н. Маковецька, М. Пантюк, О. Смирнова,Н. Стельмах, А. Федорович $[1 ; 2 ; 4 ; 7 ; 10]$. Зокрема, С. Гаврилюк висвітлила значення компетентнісного підходу для творчості педагогів у професійній підготовці сучасних вихователів, Н. Гузій обгрунтувала основи професіоналізму у підготовці майбутнього вихователя, Ю. Калічак проаналізував формування компетентності вихователя закладів дошкільної освіти в процесі професійної підготовки, М. Пантюк узагальнив роль професійно значущої мотивації у формуванні змісту професійних очікувань майбутніх вихователів закладів дошкільної освіти. Н. Стельмах визначила педагогічну творчість як фактор самореалізації особистості майбутнього вихователя, А. Федорович проаналізувала творчість вихователя як чинник ефективності навчально-виховного процесу в закладі дошкільної освіти. Метою статті $\epsilon$ аналіз методичних особливостей формування професійно-творчих можливостей вихователя майбутнього.

Виклад основного матеріалу. Формування професійно-творчих можливостей вихователя майбутнього “це цілеспрямований, довготривалий процес професійного становлення творчої індивідуальності вихователя, готового до майбутньої діяльності в умовах сучасного закладу дошкільної освіти. Адже процес творення особистості вихованця і розвиток його творчих можливостей зумовлений розвитком професійнотворчого потенціалу вихователя - носія педагогічної творчості. Як стверджує А. Федорович, у активного, творчого педагога - творчі діти. Тому що він усвідомлює потреби малюків, знає як допомогти, що запропонувати, що можна дослідити, відкрити, осягнути самостійно [10, 129].

Здатність майбутнього вихователя до професійно-творчого саморостута самовдосконалення як фахівця сприяли формуванню його творчих компетентностейі творчої поведінки, а саме вироблення індивідуального стилю діяльності та розвиток педагогічної майстерності майбутніх вихователів.

Зрозуміти природу професійно-творчих можливостей потрібно почати із визначення значення творчості. Під творчістю вчені розуміють особливу діяльність людини, ознаками якої є новизна, оригінальність, нестандартність у вирішенні питань, що вимагає певних особливих задатків. Творчість трактують, як складно організований процес, в якому людина є творцем. Тому, професійно-творчі можливості сучасного вихователя - це здатність творити нові, оригінальні ідеї, методики, технології, проекти, знаходити способи розв'язання задач професійної діяльності.

Професійно-творчі можливості вихователя майбутнього пов'язані із креативністю здатністю швидко, чітко і оригінально породжувати нові ідеї, відхилятися від традиційних схем, швидко вирішувати проблемні ситуації.

Творчий потенціал вихователя, на думку I. Шпачинського, зумовлюється особистісними психофізіологічними якостями та умовами, в яких здійснюється діяльність особистості. Від того, наскільки сприятливим для творчості $\epsilon$ навколишнє середовище, наскільки повно використовуються і заохочуються творчі можливості вихователя, настільки повною може бути реалізація творчого потенціалу $[11,4]$.

Причиною затримки формування професійнотворчого потенціалу можуть бути труднощі розвитку самого вихователя: мовленнєві проблеми, психологічна тривога, конфліктність, нестача потрібних знань, умінь і навичок, а також їх недоступність через умови життя чи індивідуальні здібності вихователя.

Ефективність освіти залежить від ступеня вираження творчих можливостей особистості студента, що зумовлює вихід із сформованих стереотипів, відмови закладів вищої освіти від стандартизації освітньо-виховного процесу, що приводить до відкритості, варіативності у навчально-виховній діяльності викладачів і студентів.

Сучасна освіта в Україні опирається на реалізацію двоєдиного завдання “ мотивація в дітей і молоді здатності, бажання та вміння навчатися протягом життя, щоб завжди бути компетентними й конкурентоспроможними, а також до навчання того, що буде основою життя й діяльності людини. Тому, як стверджує С. Гаврилюк, важливо забезпечити індивідуальну й самостійну роботу студентів, перебудувати зміст і навчальні методики на компетентнісних засадах $[1,44]$.

Формування професійно-творчого потенціалу майбутнього вихователя грунтується на таких методологічних принципах, що передбачають: визнання індивідуальності кожного студента, 


\section{ОСОБЛИВОСТІ ФОРМУВАННЯ ПРОФЕСІЙНО-ТВОРЧИХ МОЖЛИВОСТЕЙ МАЙБУТНЬОГО ВИХОВАТЕЛЯ}

врахування педагогічних задатків та мотиваційної сфери майбутнього вихователя, їх розвитку, створенню рівноправної позиції партнерів спілкування; створенню творчого середовища на діалогічній взаємодії, доброзичливості, взаємній довірі, відкритості, формування готовності висловлювати і відстоювати свою думку.

Стійка позитивна мотивація майбутнього вихователя закладу дошкільної освіти грунтується на спонуканні до досягнення високого професіоналізму у професійній діяльності, прагненні до нових ідей, а також потребі студента у саморозвитку та професійному самовдосконаленні.

Для організації розвивального освітньотворчого простору закладу вищої освіти потрібно сформувати творчу атмосферу, спонукати до творчої діяльності студентів. У закладі вищої освіти повинен бути наявний моральнопсихологічний клімат, що дозволить розширити простір для креативності та творчої праці студентів. Слід використовувати ситуації професійно-творчого успіху, педагогічний супровід. Важливе значення для майбутнього вихователя займає викладач, який повинен творчо взаємодіяти з студентом, виявляти повагу, толерантність, співтворчість, забезпечувати підтримку, надавати пораду, сприяти досягненню успіху. Все це дозволить сформувати у майбутніх вихователів знання та бажання у досягненні успіху.

Суб'єкт-суб'єктна парадигма відносин між викладачами і студентами у професійно-творчому зростанні майбутніх вихователів закладів дошкільної освіти вимагає використовувати дидактичні, дослідницькі й ділові ігри, проводити iз студентами i проводити студентські інтелектуальні ігри, навчальні тренінги і ситуаційне моделювання, навчальні дискусії, виконання творчих завдань, пов'язаних 3 виховною діяльністю.

Адже важливим аспектом формування професійно-творчих можливостей вихователя майбутнього, як зазначає М. Пантюк, є спілкування студента з людьми, які працюють за професією вихователя. Тільки вони можуть надати компетентну рекомендацію щодо проблеми та вплинути на зміст професійних очікувань [7, 14].

Семінарські заняття повинні бути змістовно наповнені, з новою інформацією та різноманітними видами пошуково-творчої діяльності. Як стверджує Р. Пріма, при вивченні різних тем 3 предмета необхідно добирати проблемні запитання та ситуації. Індивідуальні форми роботи зі студентами передбачають виконання різноманітних завдань, участь в очних і заочних олімпіадах, конкурсах [9, 207].
В Україні вводять різні програми з дошкільної освіти, які забезпечують широкий простір для професійно-творчого вихователя в організації діяльності дітей під час їх перебування у закладі дошкільної освіти у різних видах діяльності.

I. Княжева пропонує використовувати у роботі 3 студентами такі нетрадиційні методи і форми організації навчального процесу, як: проблемні лекції, лекції-візуалізації, електронні лекції, лекціїпрезентації, лекції-діалоги, метод проекту, дебати, дискусії, рольові ігри, вирішення педагогічних ситуацій, кейс-метод, педагогічний консиліум, майстер-клас, взаємонавчання, які за своєю сутністю $є$ інноваційними і вимагають від студентів оригінальних дій $[6,12]$.

Навчання в університеті й подальше професійне вдосконалення має грунтуватися на зовнішній мотивації: добре скласти тест, отримати високу оцінку, задовольнити очікування адміністрації чи батьків вихованців. Але, зовнішня мотивація може поліпшити освітню діяльність, якщо під час навчання підключити внутрішню мотивацію. Тоді бажання здобути професійну освіту не залежатиме від зовнішніх чинників, тобто педагог опановуватиме фахові знання не тому що треба, а тому що це цікаво, корисно й ефективно. Тому, як зазначає Т. Піроженко, у процесі опанування будь-якого фахового предмета потрібно створити умови, які забезпечать оптимальну складність, перспективу особистісного зростання, свободу вибору й командний дух [8, 7]. Формування професійно-творчого потенціалу ефективно розвивається у майбутніх вихователів після проходження педагогічної практики, коли теоретичні знання втілюються у конкретних педагогічних ситуаціях. На думку, Я. Квасецької, спілкування $з$ дітьми і досвідченими фахівцями сприяє розвитку у студентів, що проходять практику як професійних умінь і педагогічної майстерності, так і особистісних якостей $[5,264]$.

Для розвитку професійно-творчого потенціалу, стимулювання творчої активності ми пропонуємо студентам брати активну участь у різноманітних дискусіях. А для виявлення та розвитку професійно-творчого потенціалу майбутнього вихователя, ми радимо студентам брати участь у різних видах творчих тренінгів і проектів. Наприклад, ми пропонуємо студентам взяти участь у тренінгу “Мій ідеал акме-вихователя", в якому твердження акме студенти розумітимуть як досягнення життєвих творчих вершин у майбутній професійній діяльності педагогів. Метою цього тренінгу має бути сприяння професійному становленню кожного студента, формування позитивного самоусвідомлення, 


\section{ОСОБЛИВОСТІ ФОРМУВАННЯ ПРОФЕСІЙНО-ТВОРЧИХ МОЖЛИВОСТЕЙ МАЙБУТНЬОГО ВИХОВАТЕЛЯ}

підвищення рівня педагогічної культури. Під час тренінгу студенти повинні назвати ідеал "акмепрофесіонала вихователя" та кожен має представити його творчість за допомогою артистичних рухів. Після цього ми рекомендуємо студентам об'єднатися у групи, створити i представити групову презентацію. До акмеограми вихователя закладу дошкільної освіти студенти можуть включати такі професійні якості, як творчість, педагогічний оригінально-ініціативний оптимізм, організаційно-творчі задатки, професійно-творча зорієнтованість, мотивація до професійно-творчої діяльності, а також педагогічний артистизм, володіння педагогічною технікою, своїм настроєм.

Ми рекомендуємо студентам взяти участь у створенні проекту “Імідж сучасного вихователя”, що сприяє формуванню та засвоєнню нових технік іміджу для успішної творчої діяльності майбутнього вихователя, методиста чи завідувача закладу дошкільної освіти. Під час проекту студенти повинні об'єднатися у групи, підготувати і представити презентацію на одну із тем: "Мова вихователя”, “Зовнішній вигляд педагога”, “Невербальні засоби спілкування". Після цього для стимулювання професійно-творчого потенціалу, поглиблення знань про себе як про майбутнього педагога-майстра провести тренінгові вправи “Запрошення до чаю”, "Гусениця”, “Адаптація”, “День рекордів Гіннеса”, "Угадуємо, про кого йдеться”, “Рюкзак”, “Оживи слово”, “Рефлексивне дзеркало”, “Хто я?”, “Розповідаємо про себе”, “Головні хвилини твого життя”, “Домалюй портрет ідеального вихователя”, “Сім бажань”.

Наприклад, під час вправи “Запрошення до чаю” студенти, передаючи по колу чайну чашку, мають назвати по імені сусіда і сказати “Приходь до мене на чай, бо я...” (цікавий співрозмовник, інтелектуальна особистість, вмію розважатись). Також ми рекомендуємо для розвитку професійнотворчого потенціалу майбутніх вихователів вправу “Угадуємо, про кого йдеться", де кожний студент повинен витягнути картку із коробки, на якій зазначено слово персонажа чи предмета, якого він повинен відобразити у русі. Решта учасників повинні вгадати, кого було показано. У коробці можна подати такі слова: тигр, який пробирається джунглями, робот, орел, що літає в небі над скалами, королева Франції, інопланетянин, кипляча каструля, авторучка, в якій закінчилось чорнило, Вінні-Пух, зірка в небі, котик, який любить свого хазяїна, дитина, якій 5 років. Цікавою, на нашу думку, буде тренінгова вправа “Домалюй портрет ідеального вихователя”, в якій кожен студент повинен намалювати на аркуші одну деталь і швидко передати іншому. У кінцевому результаті має вийти портрет ідеального вихователя.

Висновки. Отже, поетапне навчання i використання нетрадиційних методів і форм організації навчального процесу, створення організаційно-педагогічних умов для реалізації отриманих знань студентами сприятимуть ефективному розвитку професійно-творчих можливостей вихователя майбутнього у педагогічному закладі вищої освіти.

Тому, викладач має якісно виявити та сформувати професійно-творчі можливості студента завдяки постійній співпраці з ним, 3 середовищем, в якому він перебуває, 3 його бажаннями і готовністю до самостійної та ініціативної діяльності, а також викликати прагнення до визначення суті та способів виконання мети - стати професійно-творчим вихователем. Адже, тільки професійно-творчий вихователь закладу дошкільної освіти може побачити в кожній дитині унікальність та творчу особистість, сформувати базу успішності для іiі майбутнього творчого розвитку.

\section{ЛІТЕРАТУРА}

1. Гаврилюк С.М. Упровадження компетентістного підходу до педагогічної творчості в професійній підготовці майбутніх вихователів. Педагогіка $i$ психологія. 2014. № 4. С. 44-49.

2. Гавриш Н. Вихователь: Хочу!? Можу!? Треба! або Професійні та особистісні цінності сучасного педагога. Вихователь-методист дошкільного закладу. 2017. № 12. С. 9-15.

3. Гевко О.I. Використання інноваційних технологій у підготовці майбутніх учителів. Професійна підготовка студентів соціальнопедагогічної сфери d освітня складова суспільного розвитку : матеріали II Міжнародної науковопрактичної конференції / За заг. ред. проф. I.М.Ковчиної. Київ, 2014. 120 с. С.19-21.

4. Калічак Ю. Формування компетентності вихователя закладів дошкільної освіти в процесі професійної підготовки. Молодь і ринок. 2018. №6. С. 65-70.

5. Квасецька Я.А. Професійна підготовка вихователів дошкілля на Західноукраїнських землях: історичний аспект: монографія. Чернівці, $2017.352 \mathrm{c}$

6. Княжева I.А. Теоретико-методологічні засади розвитку методичної культури майбутніх викладачів педагогічних дисциплін в умовах магістратури: автореф. дис. на здобуття наук. ступеня доктора пед.наук: спец. 13.00.04 “Теорія і методика професійної освіти"; 13.00 .08 “Дошкільна педагогіка”. Одеса, 2014. 45 с. 


\section{ОСОБЛИВОСТІ ФОРМУВАННЯ ПРОФЕСІЙНО-ТВОРЧИХ МОЖЛИВОСТЕЙ МАЙБУТНЬОГО ВИХОВАТЕЛЯ}

7. Пантюк М. Роль професійно значущої мотивації у формуванні змісту професійних очікувань майбутніх вихователів закладів дошкільної освіти. Молодь і ринок. 2015. № 12. C. $10-15$.

8. Піроженко Т. Якщо очікуєш змін - змінюйся сам. Вихователь-методист дошкільного закладу. 2017. № 12. С. 4-8.

9. Пріма Р.М. Робота 3 обдарованими студентами: теоретико-прикладні аспекти. Вищза освіта Украӥни. 2014. Т. 2, № 3. С. 201-210.

10. Федорович А. Творчість вихователя як чинник ефективності навчально-виховного процесу в дошкільному навчальному закладі. Молодь і ринок. 2016. № 10. С. 127-131.

11. Шпачинський І.Л. Творчий потенціал особистості і його реалізація в умовах трансформації суспільства: автореф. дис. на здобуття наук. ступеня канд. філософ. наук: спец. 09.00.03 “Соціальна філософія та філософія історії. Одеса, 2006. 20 с.

\section{REFERENCES}

1. Havryliuk, S. M. (2014). Uprovadzhennia kompetentistnoho pidkhodu do pedahohichnoi tvorchosti $\mathrm{v}$ profesiinii pidhotovtsi maibutnikh vykhovateliv [Implementation of a competent approach to pedagogical creativity in the professional training of future educators]. Pedagogy and psychology. No. 4, pp. 44d49. [in Ukrainian].

2. Havrysh, N. (2017). Vykhovatel: Khochu!? Mozhu!? Treba! abo Profesiini ta osobystisni tsinnosti suchasnoho pedahoha [Educator: I want to !? Can!? Need! or Professional and personal values of the modern educator]. Educational methodologist of preschool institution. No. 12, pp. 9-15. [in Ukrainian].

3. Hevko, O. I. \& Kovchyna, I. M. (2014). Vykorystannia innovatsiinykh tekhnolohii u pidhotovtsi maibutnikh uchyteliv [Use of innovative technologies in the preparation of future teachers]. Vocational training of students of social and pedagogical sphere $d$ educational component of social development: Proceedings of the II International Scientific-Practical Conference. Kyiv: NPU imeni M.P. Drahomanova, 120 p., pp. 19-21. [in Ukrainian].

4. Kalichak, Yu. (2018). Formuvannia kompetentnosti vykhovatelia zakladiv doshkilnoi osvity v protsesi profesiinoi pidhotovky [Formation of competency of the preschool teacher in the process of vocational training]. Youth and market. No. 6, pp. 65-70. [in Ukrainian].

5. Kvasetska, Ya. A. (2017). Profesiina pidhotovka vykhovateliv doshkillia na Zakhidnoukrainskykh zemliakh: istorychnyi aspekt: monohrafiia [Professional training of preschool teachers in Western Ukraine: historical aspect: monograph]. Chernivtsi, 352 p. [in Ukrainian].

6. Kniazheva, I. A. (2014). Teoretykometodolohichni zasady rozvytku metodychnoi kultury maibutnikh vykladachiv pedahohichnykh dystsyplin v umovakh mahistratury [Theoretical and methodological foundations of development of methodological culture of future teachers of pedagogical disciplines in the conditions of magistracy]. Extended abstract of Doctor's thesis. Odessa, 45 p. [in Ukrainian].

7. Pantiuk, M. (2015). Rol profesiino znachushchoi motyvatsii u formuvanni zmistu profesiinykh ochikuvan maibutnikh vykhovateliv zakladiv doshkilnoi osvity [The role of professionally significant motivation in shaping the content of professional expectations of future preschool educators]. Youth and market, no. 12, pp. 10-15. [in Ukrainian].

8. Pirozhenko, T. (2017). Yakshcho ochikuiesh zmin - zminiuisia sam [If you expect change d change yourself]. Educational methodologist of preschool institution, no. 12, pp. 4d8. [in Ukrainian].

9. Prima, R. M. (2014). Robota z obdarovanymy studentamy: teoretyko-prykladni aspekty [Working with gifted students: theoretical and applied aspects]. Higher education in Ukraine, vol. 2, no. 3, pp. 201210. [in Ukrainian].

10. Fedorovych, A. (2016). Tvorchist vykhovatelia yak chynnyk efektyvnosti navchalno-vykhovnoho protsesu v doshkilnomu navchalnomu zakladi [Creator Creativity as a Factor of Efficiency of Educational Process in Preschool Institution]. Youth and market, no. 10, pp. 127-131. [in Ukrainian].

11. Shpachynskyi, I. L. (2006). Tvorchyi potentsial osobystosti i yoho realizatsiia v umovakh transformatsii suspilstva [The creative potential of the individual and its realization in the conditions of transformation of society]. Extended abstract of candidate's thesis. Odessa, 20 p. [in Ukrainian].

Стаття надійшла до редакції 04.10.2019

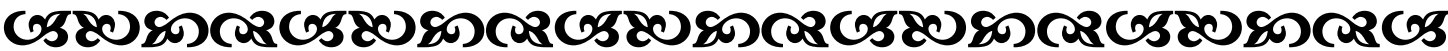

"Яћщо ви вдало виберете пращю $і$ вкладете в неї всю свою душу, то щастя само знайде вас".

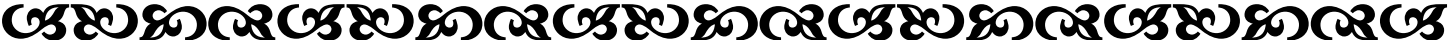

